\title{
A Study on the Effect of Consulting Company's signaling factors on Trust and Intention of Clients -Targeting Franchise companies-
}

\author{
Minhee Kwon, Dept. of Smart Convergence Consulting, Hansung University, Seoul, 02876, Korea \\ *Yen-yoo You, Dept. of Smart Convergence Consulting, Hansung University, Seoul, 02876, Korea, \\ threey0818@hansung.ac.kr \\ ${ }^{*}$ Corresponding author
}

\begin{abstract}
Background/Objectives: This study aims to identify the relationship between the signal factors of the consulting firm on the client's trust and intention, anticipate the interaction relationship, and contribute to the development of competitiveness in the business by effectively recognizing the client's capabilities and securing strategy to the consulting order.

Methods/Statistical analysis: This study conducted a survey of employees working at franchise companies to find out the cause and effect of the client's trust and contract. Questionnaire composed of Likert's 5-point scale. Using SPSS win version 20.0 and AMOS 20.0 statistical tools, collected samples were analyzed by validity and reliability analysis, and multiple regression analysis.

Findings: This study established the hypothesis of structural relationship that the signal factor of the consulting firm affects the client's trust and the degree of contract, and conducted verification through empirical analysis. Analysis of the impact of the signal factor of the consulting firm on the client's trust showed that the five factors, Assurance, Reliability, Empathy, Responsiveness and Tangibles that make up the signal factor of the consulting firm had a positive effect on cognitive and emotional dimension. On the other hand, the last signal factor, Promotion, was not significant. Among the signal factors of consulting firms, signals that have a high influence on cognitive trust were shown sequentially with Reliability, Assurance, Tangibles, Responsiveness and Empathy. It was also shown that both cognitive and emotional dimension have been shown to have a positive effect on the client's intention, especially emotional dimension has a higher impact on the client's intention than on cognitive trust.

Improvements/Applications: this study identified the signal factors of the consulting firm. There may be limitations as a composition of signal factors for consulting firms, so detailed signals need to be considered.
\end{abstract}

Keywords: Signal Theory, Consulting, Trust, Contract intention, Purchasing agreement, Dimension Received: 08.12.2020 $\quad$ Accepted: 10.01.2021 $\quad$ Published: 03.02.2021

\section{INTRODUCTION}

The business environment is rapidly changing due to internal and external circumstances, and the consulting industry is also growing along with a surge in demand for consulting, which is an objective and independent entity rather than a company's position to diagnose and resolve various problems facing the company through management improvement and restructuring. Knowledge in the 21st century is the most important asset in the organization [1], and the consulting industry is typically the industry that provides services based on knowledge [2].

Although the size of the domestic consulting market and the infrastructure of employees are expanding, the domestic consulting industry has a shorter operational age and is also small in terms of scale and history compared to developed countries [3]. Moreover, as IT technologies such as Fin-Tech develop, interest in the service industry included consulting is also increasing [4]. In other industry, medical and health care industry, the quality of care is measured by just the quality of tools. But these days, the satisfactions with perceptions of patients are emerging as an important point [5]. In addition, marketing factors such as advertising must be important factors that drive consumer awareness and satisfaction and drive action [6].

Therefore, we would like to identify the relationship between the signal factor of the signal consultant, which is the factor in identifying the hidden information [7], and the reliability and intention of the client and present the results. Through these studies, consulting firms can expect how they can express their capabilities as consultants providing professional services to the market and interact with clients' confidence and contract levels, especially by using limited resources to effectively recognize their specialized capabilities to clients and secure a strategy to link them to consulting orders. In addition to 
being applied as a competitive advantage that can be utilized by consulting firms, the Commission intends to contribute to securing third-party capabilities and fostering competitiveness as a consulting firm by recognizing the needs and information required by clients.

\section{Materials and methods}

\subsection{Analysis method}

The purpose of this study is to establish the relationship between the client's trust and intention of the consulting firm to the franchise company. Therefore, the survey was conducted on employees working for domestic franchise companies. To verify the validity of the measurement factors used in this study, the factorial goodness-of-fit index loaded on each factor was analyzed through a confirmatory factor analysis, and the composite reliability (CCR) and average variance extraction (AVE) were determined, and finally the structural equation model was verified based on the hypotheses and models of the study. All of the above analyses used SPSS Win Ver. 20.0 and AMOS 20.0.

\subsection{Research model}

In this study, we look at how the signal factors of consulting firms affect clients' trust and intention to help the majority of the relatively small domestic consulting firms effectively recognize their specialized capabilities to clients by utilizing limited resources and secure a strategy to link them to consulting orders to conduct their business. In order to achieve the objectives of this research, the preceding research has derived six factors of assurance, reliability, empathy, responsiveness, tangibles, and promotion as the signal factors of the consulting firm, and the research model has been constructed as shown in [Figure 1] below.

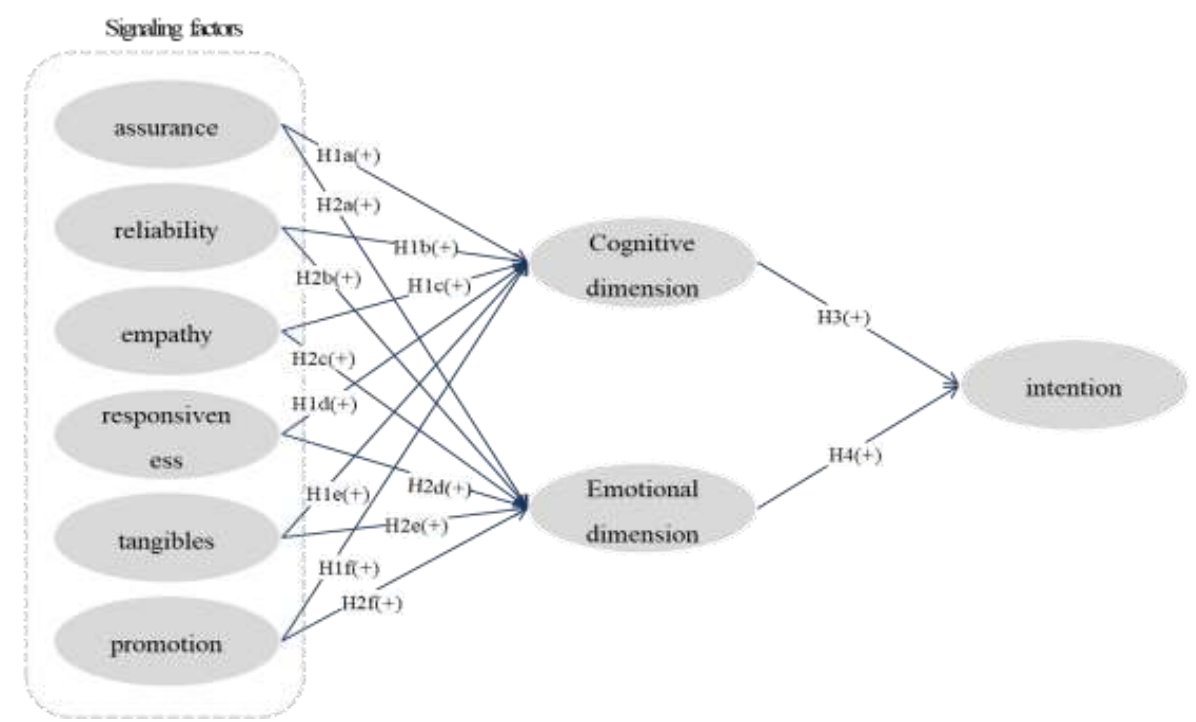

Figure 1 Research model

\subsection{Research hypothesis}

Based on the previous research, this study established a hypothesis about how consulting company's signaling factors attributes of trust and intention.

H1a. Assurance will have a positive effect on the client's cognitive dimension.

H1b. Reliability will have a positive effect on the client's cognitive dimension.

H1c. Empathy will have a positive effect on the client's cognitive dimension.

H1d. Responsiveness will have a positive effect on the client's cognitive dimension.

H1e. Tangibles will have a positive effect on the client's cognitive dimension.

H1f. Promotion will have a positive effect on the client's cognitive dimension.

H2a. Assurance will have a positive effect on the client's emotional dimension.

H2b. Reliability will have a positive effect on the client's emotional dimension.

H2c. Empathy will have a positive effect on the client's emotional dimension.

H2d. Responsiveness will have a positive effect on client's emotional dimension. 
H2e. Tangibles will have a positive effect on the client's emotional dimension.

H2f. Promotion will have a positive effect on the client's emotional dimension.

H3. Cognitive dimension will have a positive effect on the client's intention.

H4. Emotional dimension will have a positive effect on the client's intention.

\subsection{Definition of variables}

In this study, we look at how the signal factors of consulting firms affect clients' trust and intention to help the majority of the Based on the previous research, this study set a hypothesis about how consulting company's signaling factors attributes of trust and intention based on [table 1].

Table1 Verification of Research Model

\begin{tabular}{|c|c|c|c|c|}
\hline \multicolumn{2}{|l|}{ Prime Variables } & $\begin{array}{l}\text { question } \\
\text { s }\end{array}$ & measurement & source \\
\hline \multirow{6}{*}{$\begin{array}{l}\text { Signal } \\
\text { factors }\end{array}$} & Assurance & 4 & $\begin{array}{l}\text { - The consulting firm is building an information } \\
\text { network through networks in various fields. } \\
\text { - The consulting firm has consulting analyzer } \\
\text { methods and tools. } \\
\text { - The consulting firm has sufficient experience } \\
\text { in the area. } \\
\text { - Consultants have abundant qualifications and } \\
\text { experience for consultants }\end{array}$ & $\begin{array}{l}\text { Parasurama } \\
\mathrm{n}(1991)[8]\end{array}$ \\
\hline & Reliability & 4 & $\begin{array}{l}\text { - The consulting firm's corporate image is } \\
\text { excellent. } \\
\text { - The consulting firm provides competitive fees } \\
\text { (consulting costs). } \\
\text { - The data and indicators provided by the } \\
\text { consulting firm are accurate. } \\
\text { - The consulting firm provides context-sensitive } \\
\text { services based on experience. }\end{array}$ & \multirow{4}{*}{$\begin{array}{l}\text { Parasurama } \\
\text { n (1991)[8] } \\
\text { Park B. H., } \\
\text { Lee D. W., } \\
\text { Kim Y. S } \\
(2005)[9] \\
\text { Rhim H. S., } \\
\text { Baek S. K., } \\
\text { Her H. Y } \\
(2005)[10]\end{array}$} \\
\hline & Empathy & 5 & $\begin{array}{l}\text { - The consulting firm prioritizes client } \\
\text { confidentiality } \\
\text { - The consultant understands the client's needs } \\
\text { well. } \\
\text { - Consultants are individually interested in } \\
\text { clients. } \\
\text { - It is easy to contact consulting firms and } \\
\text { conduct meetings. } \\
\text { - The consulting firm provides follow-up } \\
\text { services such as feedback on consulting. }\end{array}$ & \\
\hline & $\begin{array}{l}\text { Responsive } \\
\text { ness }\end{array}$ & 3 & $\begin{array}{l}\text { - Consultants respond immediately to client } \\
\text { needs. } \\
\text { - The consulting firm will provide accurate } \\
\text { information on current and future progress. } \\
\text { - The consulting firm is always prepared to help } \\
\text { the client. }\end{array}$ & \\
\hline & Tangibles & 5 & $\begin{array}{l}\text { - The consulting firm has a consultant as a full- } \\
\text { time employee. } \\
\text { - The consulting firm has a long history. } \\
\text { - The consulting firm provides sufficient data } \\
\text { such as strategic documents and manuals. } \\
\text { - The consultant is qualified to perform a } \\
\text { degree, certificate, etc. } \\
\text { The consulting firm has a case of success. }\end{array}$ & \\
\hline & Promotion & 4 & $\begin{array}{l}\text { - The consulting firm has an excellent } \\
\text { reputation and recommendations around it. }\end{array}$ & $\begin{array}{l}\text { Kim T. H., } \\
\text { Cho M. O. \& }\end{array}$ \\
\hline
\end{tabular}


- The consulting firm provides various Joo S. H. information through newspapers and (2012)[11] magazines.

- The consulting firm provides various information through blogs and social networking sites.

- The consulting firm publishes various information through professional books and papers.

- The consulting firm seems to have excellent technical skills.

Cognitive 3 - Consulting firms seem to have expertise dimension 3 within their fields.

- The consulting firm seems to have specialized know-how.

Park J. C.,

Trust

(dimension)

Emotional dimension

intention

- The information provided by the consulting

Ryu G. S. firm is reliable.

- The consulting firm is likely to be sincere in proceeding with the project.

- The consulting firm is likely to be honest in its business.

- I want to be a business partner with the consulting firm.

- I am interested in the consulting firm.

- I would like to make a consulting contract with the consulting firm.

- If there is a need for consulting requests in the future, we will sign a contract with the consulting firm.
Kim T. H., Cho M. O. \& Joo S. H. (2012)[11] Park K. Y., Park J. Y., You Y. Y. (2011)[13]

\section{Results and Discussion}

\subsection{Confirmatory factor analysis}

In this study, to verify the theoretical research model set up, a confirmatory factor analysis was conducted to verify the measurement model for each factor. A confirmatory factor analysis looks at the suitability of a measurement model that measures the relationship between the concept and the measurement item. Before looking at the impact relationships of models set up in this study, a measurement variable was conducted to analyze whether the structure was reasonable as a factor supporting the theoretical variable.

As a result of the confirmatory factor analysis for the theoretical model set up in this study, $\mathrm{x}^{2}$ was found to be $1144.037(\mathrm{df}=524, \mathrm{p}<0.001)$, while indices were $\mathrm{GFI}=0.865, \mathrm{NFI}=0.826$ and $\mathrm{CFI}=0.897$.

It is known that it is suitable when AVE is 0.5 or higher and CCR is 0.7 or higher [14], AVE for each concept of the measurement tool for this study is 0.568 or higher and CCR is 0.799 or higher, indicating that the concentrated feasibility of the measurement variables has been secured.

Standardized loadings, Estimate, C.R. values, AVE, and CCR values for each measurement item are shown in [Table 2].

Table2 Confirmatory factor analysis

\begin{tabular}{|c|c|c|c|c|c|c|}
\hline Latent variable & $\begin{array}{l}\text { Standardize } \\
\text { d factor lo } \\
\text { ading }\end{array}$ & Estimate & S.E & C.R & AVE & CCR \\
\hline Assurance & 0.764 & 1 & & & 0.711 & 0.912 \\
\hline
\end{tabular}




\begin{tabular}{|c|c|c|c|c|c|c|c|}
\hline & $\mathrm{a} 2$ & 0.820 & 1.16 & 0.09 & $12.842^{* * *}$ & & \\
\hline & a3 & 0.862 & 1.221 & 0.089 & $13.647^{* * *}$ & & \\
\hline & $\mathrm{a} 4$ & 0.919 & 1.304 & 0.089 & $14.714^{* * *}$ & & \\
\hline & r1 & 0.720 & 1 & & & & \\
\hline & r2 & 0.727 & 1.103 & 0.105 & $10.46^{* * *}$ & & \\
\hline Rellabillty & r3 & 0.814 & 1.157 & 0.099 & $11.741^{* * *}$ & 0.584 & 0.823 \\
\hline & r4 & 0.791 & 1.106 & 0.097 & $11.399 * * *$ & & \\
\hline & e1 & 0.743 & 1 & & & & \\
\hline & $\mathrm{e} 2$ & 0.864 & 1.031 & 0.08 & $12.932^{* * *}$ & & \\
\hline Empathy & e3 & 0.636 & 0.602 & 0.096 & $6.243^{* * *}$ & 0.578 & 0.913 \\
\hline & $\mathrm{e} 4$ & 0.735 & 0.902 & 0.083 & $10.84^{* * *}$ & & \\
\hline & e5 & 0.803 & 0.933 & 0.078 & $11.953^{* * *}$ & & \\
\hline & re1 & 0.820 & 1 & & & & \\
\hline $\begin{array}{l}\text { Responsivene } \\
\text { SS }\end{array}$ & re2 & 0.874 & 1.144 & 0.075 & $15.317^{* * *}$ & 0.680 & 0.845 \\
\hline & re3 & 0.777 & 1.03 & 0.08 & $12.946^{* * *}$ & & \\
\hline & $\mathrm{t} 1$ & 0.770 & 1 & & & & \\
\hline & $\mathrm{t} 2$ & 0.614 & 0.921 & 0.111 & $8.324^{* * *}$ & & \\
\hline Tangibles & $\mathrm{t} 3$ & 0.862 & 1.183 & 0.105 & $11.22^{* * *}$ & 0.547 & 0.852 \\
\hline & t4 & 0.646 & 0.871 & 0.117 & $7.474^{* * *}$ & & \\
\hline & $\mathrm{t} 5$ & 0.779 & 0.933 & 0.091 & $10.297^{* * *}$ & & \\
\hline & p1 & 0.702 & 1 & & & & \\
\hline & $\mathrm{p} 2$ & 0.750 & 1.268 & 0.126 & $10.03^{* * *}$ & & \\
\hline 1 1 & p3 & 0.755 & 1.228 & 0.122 & $10.09^{* * *}$ & 0.500 & על 0.1 \\
\hline & $\mathrm{p} 4$ & 0.805 & 1.41 & 0.132 & $10.683^{* * *}$ & & \\
\hline & $\mathrm{d} 1$ & 0.853 & 1 & & & & \\
\hline $\begin{array}{l}\text { Cognitive Dim } \\
\text { ension }\end{array}$ & $\mathrm{d} 2$ & 0.895 & 1.016 & 0.057 & $17.867^{* * *}$ & 0.802 & 0.924 \\
\hline & d3 & 0.937 & 1.055 & 0.054 & $19.523^{* * *}$ & & \\
\hline & $\mathrm{d} 4$ & 0.911 & 1 & & & & \\
\hline $\begin{array}{l}\text { Emotional Di } \\
\text { mension }\end{array}$ & d5 & 0.870 & 0.941 & 0.049 & $19.19^{* * *}$ & 0.777 & 0.902 \\
\hline & d6 & 0.862 & 0.948 & 0.05 & $18.807^{* * *}$ & & \\
\hline & i1 & 0.886 & 1 & & & & \\
\hline Intention & i2 & 0.910 & 1.023 & 0.05 & $20.41 * * *$ & 0.812 & 0.942 \\
\hline
\end{tabular}




\subsection{Verification of Research model}

Analysis Results of Research Model, it was statistically significant at the level of $\chi^{2}=1376.238(\mathrm{df}=546$, $\mathrm{p}<0.001$ ). Looking at the [table 3], GFI $=0.822, \mathrm{RMR}=0.059, \mathrm{NFI}=0.823$, and $\mathrm{CFI}=0.87$, it appears that the overall model is satisfactory, and the relationship model presented in the study is consistent with the actual analysis at a satisfactory level. Based on this, the path coefficients for each factor can be expressed as follow [table 3].

Table3 Verification of Research Model

\begin{tabular}{lllllll}
\hline- & $\chi^{2}$ & p-value & GFI & CFI & NFI & RMR \\
\hline Model & 1376.238 & 0.000 & 0.822 & 0.870 & 0.823 & 0.059 \\
\hline
\end{tabular}

\subsection{Results of Research}

First of all, as a result of the hypothesis test of the impact of the consulting company's signal factors on client's cognitive dimension, Assurance, Reliability, Empathy, Responsiveness, and Tangibles have a significant effect on cognitive dimension. Each factor's non-standardized coefficient is $0.389,0.638,0.169$, $0.117,0.344$, and C.R. is 6.710, 8.584, 3.190, 2.261, and 5.951. However, the last signal factor, Promotion, rejected on cognitive dimension with non-standardized coefficient -.0.033, C.R. -0.640.

As a result of the hypothesis test of the impact of the consulting company's signal factors on client's emotional dimension, Assurance, Reliability, Empathy, Responsiveness, and Tangibles have a significant effect on cognitive dimension. Each factor's non-standardized coefficient is $0.270,0.629,0.232,0.306$, 0.340 , and C.R. is 5.002, 8.816, 4.230, 5.537, and 5.917. However, as the above hypothesis, Promotion is rejected on cognitive dimension with non-standardized coefficient -.0.033, C.R. -0.640.

As a result of the hypothesis test on the effect of client trust on the contract intention, cognitive dimension has a significant effect with path coefficient of 0.340 and C.R. 4.318 ( $<<0.001)$. Emotional dimension was also shown to have a significant effect on the path coefficient of 0.555, C.R. 6.670 $(\mathrm{p}<0.001)$. Therefore, the study theories $\mathrm{H} 3$ and $\mathrm{H} 4$ were adopted, indicating that trust had a positive effect on the contract's intention, and emotional trust had a higher effect on the contract's validity than cognitive trust.

Detailed hypothesis test results are shown in the [table 4] below.

Table 4 The effect of Signal factors on client's trust and intention

\begin{tabular}{llllll}
\hline Division & $\begin{array}{l}\text { Non- } \\
\text { standardized } \\
\text { Coefficient }\end{array}$ & $\begin{array}{l}\text { Standardization } \\
\text { Coefficient }\end{array}$ & C.R.. & P-value & Result \\
\hline H1a & 0.389 & 0.053 & 6.710 & $* * *$ & Not Reject \\
H1b & 0.638 & 0.071 & 8.584 & $* * *$ & Not Reject \\
H1c & 0.169 & 0.048 & 3.190 & 0.001 & Not Reject \\
H1d & 0.117 & 0.046 & 2.261 & 0.024 & Not Reject \\
H1e & 0.344 & 0.049 & 5.951 & $* * *$ & Not Reject \\
H1f & -0.033 & 0.061 & -0.640 & 0.522 & Reject \\
H2a & 0.270 & 0.052 & 5.002 & $* * *$ & Not Reject
\end{tabular}




\begin{tabular}{llllll}
$\mathrm{H} 2 \mathrm{~b}$ & 0.629 & 0.072 & 8.816 & $* * *$ & Not Reject \\
$\mathrm{H} 2 \mathrm{c}$ & 0.232 & 0.053 & 4.230 & $* * *$ & Not Reject \\
$\mathrm{H} 2 \mathrm{~d}$ & 0.306 & 0.051 & 5.537 & $* * *$ & Not Reject \\
$\mathrm{H} 2 \mathrm{e}$ & 0.340 & 0.051 & 5.917 & $* * *$ & Not Reject \\
$\mathrm{H} 2 \mathrm{f}$ & 0.082 & 0.066 & 1.547 & 0.122 & Reject \\
$\mathrm{H} 3$ & 0.340 & 0.095 & 4.318 & $* * *$ & Not Reject \\
$\mathrm{H} 4$ & 0.555 & 0.096 & 6.670 & $* * *$ & Not Reject \\
\hline
\end{tabular}

\section{Conclusions}

Consulting demand is increasing in Korea as the consulting market expands, but the volume of domestic consulting firms, except large foreign consulting firms, is still small. Various studies have been conducted to strengthen consulting firms' capabilities, but research with actual consulting orders and contracts is somewhat lacking. Based on this background, recognizing the need for research on how to build trust with clients and affect the degree of contract when expressing the competence held as a consulting firm, this study established the hypothesis of structural relationship. And signal factors of the consulting firm affect the client's trust and intention and conducted verification through empirical analysis.

This study analyzed the signal factors of the consulting firm that affect client trust and intention. Through this, we identified the signal factors of the consulting firm, which are the factors that effectively express the capabilities of the consulting firm, and looked at which signal factors are effectively recognized by clients to link them to consulting orders. Therefore, consultants will need to be able to connect to consulting orders by enhancing the capabilities of the client's significant considerations. In addition, this study was conducted on franchisers, and further research should be conducted on clients in different industries and other consulting fields to study the signal factors felt by clients in each industry.

\section{Acknowledgements}

This research was financially supported by Hansung University.

\section{References}

[1] Stankosky MA. Advances in knowledge management: University research toward an academic discipline. InCreating the discipline of knowledge management 2005 Jan 1 (pp. 1-14). ButterworthHeinemann

[2] Sarvary M. Knowledge management and competition in the consulting industry. California management review. 1999 Jan;41(2):95-107.

[3] Shin TH, Shin SW, Kwak HJ. The Current Status and Future Challenge for the Development of Korea Consulting Industry. Journal of the Korea Service Management Society. 2006;7(2):171-200.

[4] Mun HJ, Kang SY, Shin C. Implementation of Secure Keypads based on Tetris-Form Protection for Touch Position in the Fintech. Journal of Convergence for Information Technology. 2020;10(8):144-51.

[5] Kateel N, Koodamara NK. A Study on Patient Satisfaction: Differences in Private and Public Hospitals. INTERNATIONAL JOURNAL OF EMERGING MULTIDISCIPLINARY RESEARCH (IJEMR). 2018 Mar 31;2(1):33-9.

[6] Jain D, Jain P. Online Advertising-Transforming the Masses. INTERNATIONAL JOURNAL OF EMERGING MULTIDISCIPLINARY RESEARCH (IJEMR). 2018 Mar 31;2(1):41-6.

[7] Spence AM. Market signaling: Informational transfer in hiring and related screening processes. Harvard Univ Pr; 1974.

[8] Parasuraman A, Berry LL, Zeithaml VA. Refinement and reassessment of the SERVQUAL scale. Journal of retailing. 1991 Dec 1;67(4):420.

[9] Park BH, Lee DW, Kim YS. Measuring service quality of management consulting. Journal of the Korean society for Quality Management. 2005;33(3):47.

[10] Rhim HS, Baek SK, Her HY. Service quality and customer satisfaction in IT consulting service. Journal 
of Korea Service Management Society. 2005 Aug;6(2):3-19.

[11] Kim TH, Cho MO, Joo SH. Effect of Franchisor's Signaling Factors on the Trust Awareness and to the Business Contract Intention of Pre-franchisee. Journal of Foodservice Management Society of Korea. 2014;17(2):49-73.

[12] Park JC, Ryu GS. The effects of corporate ability and social responsibility associations on customer attitudes: The mediating role of credibility-and benevolence-based Trust. Journal of Korean Marketing Association. 2012;27(1):1-25.

[13] Park KW, Park JY, You YY. Influence of consumers' shopping value and product types on LOHAS consumption. The Journal of the Korea Contents Association. 2011;11(12):856-69.

[14] Hair J, Black W, Babin B, Anderson R. Exploratory factor analysis multivariate data analysis. 